\title{
プリント回路の電磁特性研究における最近の進展 一電磁特性研究会活動紹介一
}

\author{
越地 耕二*1, 林 昌世*2, 澤佐 博行*1, 和田 修己*3, 高橋 丈博*4, 堀田 幸雄*5, \\ 松永 茂樹*6, 諸橋 欣一*7, 勅使河原 治*8
}

\section{Advances in Research for Electromagnetic Characteristics of Printed Circuits -Recent Activity of Research Group for Electromagnetic Behavior-}

Kohji KOSHIJI ${ }^{* 1}$, Sho-se HAYASHI ${ }^{* 2}$, Hiroyuki SAWASA ${ }^{* 1}$, Osami WADA ${ }^{* 3}$, Takehiro TAKAHASHI ${ }^{* 4}$, Yukio HOTTA ${ }^{* 5}$,Shigeki MATSUNAGA ${ }^{* 6}$, Kinichi MOROHASHI $^{* 7}$ and Osamu TESHIGAWARA ${ }^{* 8}$

\footnotetext{
*1 東京理科大学理工学部電気工学科（テ278 千葉県野田市山崎2641）

*2＼cjkstart株式会社NEC情報システムズ科学技術部（テ213 神奈川県川崎市高津区坂戸3-2-1）

*3 岡山大学工学部電気電子工学科 (テ700 岡山県岡山市津島中3-1-1)

*4 拓殖大学工学部情報工学科（干193 東京都八王子市館町815-1）

*5 株式会社トーキン, EMC事業部（テ213 神奈川県川崎市高津区子母口398）

*6 株式会社トクヤマ電子基材事業部（テ243 神奈川県厚木市田村町8-8柳田ビル1F）

*7 株式会社シイエムケイ回路設計センター（テ354 埼玉県入間郡三芳町藤久保1106）

*8 日本無線株式会社研究所（†356 埼玉県上福岡市福岡2-1-4）

*1 Department of Electrical Engineering, Faculty of Science and Technology, Science University of Tokyo (2641 Yamazaki, Noda-shi, Chiba 278)

*2 Scientific \& Engineering Analysis Dept.,NEC Informatec Systems,Ltd. (3-2-1 Sakado,Takatsu-ku, Kawasaki-shi, Kanagawa 213)

*3 Department of Electrical Engineering, Faculty of Engineering, Okayama University (3-1-1 Tsushima-Naka, Okayama-shi, Okayama 700)

*4 Department of Computer Science, Faculty of Engineering, Takushoku University (815-1 Tatemachi, Hachioji-shi, Tokyo 193)

*5 EMC Division, Tokin Corporation (398 Shibokuchi, Takatsu-ku, Kawasaki-shi, Kanagawa 213)

*6 Electronics Dept., Tokuyama Corp. (Yanagida Build., 8-8 Tamura-cho, Atsugi-shi, Kanagawa 243)

*7 Circuit Design Center,CMK Corp. (1106 Fujikubo, Miyoshi-machi, Iruma-gun, Saitama 354)

*8 Laboratory, Japan Radio Co.,Ltd. (2-1-4 Fukuoka, Kamifukuoka-shi, Saitama 356)
}

\section{1.まえがき}

電子機器類の回路実装は, 軽・薄・短・小を合言葉に高 密度化の一途をたどってきた。高密度実装は単に回路や部 品類の小型化によって実現されるというものではなく，製 品が必要とされる性能を発揮するためには，電磁気学的な 視点に立った研究・開発・設計がきわめて重要となる。こ こでは, 本学会電磁特性研究会に打ける, 過去 4 年間のプ リント回路の電磁気学的な視点に立った研究の進展につい て紹介する。同研究会では，運営委員会（年6回程度）お よび公開研究会（年3回）を開催し, 公的印刷物として公 開研究会論文集，研究会活動報告書を発行している。これ らの印刷物における報告または論文の掲載件数は100件を 上回る。この数字は4年間の積み重ねとはいえ，会員諸氏 のこの分野への関心の深さと, アクティヴィティの高さを 物語っている。

本稿は, EMC対策の理論（解析, 測定), EMC対策の実
践 (部品, 材料, 回路設計), その他として分類され, 記 述されている。また，本会以外の報告や論文も重要と思わ れるものについては引用・紹介を行っている。

\section{EMI対策の理論}

EMI対策とは不要電磁波を低減する対策である。基礎電 磁界理論，伝送線路理論とアンテナ理論を勉学することは, EMI対策の理論を導くことに役立つことが多いA1)。しかし ながら，実機は製品ごとに電磁的条件が違うため, 各々の 問題を定式化して記述するには基本的電磁現象を記述する 支配方程式までさかのぼって検討する必要がある場合がよ くある。実機の対策には，ほとんどの場合実機の現状を把 握する測定がまず必要である。それと平行に, 解析手法を 用いて電磁特性を表す变数間の関係を定量的に表すことが できると，実機の電磁特性を理解しやすくする。したがっ て, EMI対策を開発するときに「測定」と「解析」の手法を併 用すると，非常に有利になるといえる。

○執筆担当：越地 耕二 (1節,5節)，林 昌世 (2節,2.1節)，澤佐 博行 (2.1節)，和田 修己 (2節,2.2節)，高橋 丈博（2節,2.2節)，堀田 幸雄（3節,3.1節)， 松永 茂樹 (3節,3.2節)，諸橋 欣一 (3節,3.3節)，勅使河原 治 (4節) 
次の 2 節では最近 4 年間の電磁特性研究会で発表された 論文のうち, 普遍的な対策を発見しようと図る研究で, 測 定と解析に関連ある論文を網羅して，解説を試みた。2.1 では解析手法を用いて行った研究およびEMIシミュレータ に関連する研究を主体に, 最近の解析についての研究進展 について解説する。2.2では各種測定手法，および測定に よって明らかになった電磁特性に関する研究の進展につい て解説する。

\section{1 解析理論関連}

「解析」という用語は，一般にはよく電磁界解析，すな わち電磁波，電磁界の計算法のことをさすことが多( (A2),A3) $^{\circ}$ しかし，本節ではもっと広い意味で使うことにする。

実機のEMI対策を考えるとする。本質的には 3 次元の電 磁界は, 周波数分布と境界条件が複雑であるため, 実機の 電磁界の時空間分布は複雑であるといえる。そのような情 況では, 実機の電磁特性を数学的に定式化することは決し て容易ではない。対策を導くために, どのような電磁的物 理量をどう計算すればいいかがわからないことが多い。そ こで，普遍的な対策を導出するためによく興味ある物理関 係だけを抽出したモデルを作って, 変数間の関係を解明す る調査手法が使われる。ここではこのようにモデルを設定 し，解を算出するプロセスを「解析」と定義する。

このようにモデルを使った電磁特性の解析はEMI対策を 開発する基礎となる。それと同時に, 蓄積された解析の結 果は, 後日利用されて普遍的な法則の導出に結びつく可能 性が潜む。したがって，モデルを基に解析することは，実 機の対策の導出にアプローチする1つの有効な手段である。

EMI対策の開発には，以上のようにモデルを構築し， EMI対策と関連ある物理を明らかにする解析的手法によっ てアプローチする攻め方がある。一方，最近は実用性を目 的に，低ノイズ基板を設計するためのシミュレータに関す る研究調查も目覚ましい。シミュレータは物理モデルがす でに正しいという仮定から出発し，既知の変数を入力して， 知りたい変数を計算する数值実験（シミュレーション）で ある。通常, シミュレータのアルゴリズムは発表論文に詳 細な記述をしないことが多い。そのため，残念ながら，効 果評価についての正確な情報の入手は非常に難しい。本研 究会では以下に述べるごとく，このような情報を交換する 機会も提供された。

西方敦博 ${ }^{14)}$ は無限平板の遮蔽効果を解析した。この論文 は微小ダイポール波源に対する無限平板導体遮蔽の解析を 拡張して多層基板モデルである多層無限平板のGreen関数 を定式化し, 近傍電磁界の定式化を行った。長尾泰司, 他 ${ }^{87}$ は平板シールドに影響された近傍電磁界の解析を行った。 シールド通過後の電磁界は多重極展開による波源で表現さ れている。ここで用いたモデルは微小電気ダイポールと微 小磁気ダイポールの2種類の波源，材質は銅の平板， $100 \mu$ $\mathrm{m}$ と $1 \mathrm{GHz}$ の周波数である。このモデルでは厳密解は既知
であるので, 多重極展開式の未定係数は一意的に決められ た。解析結果によると, 波源が微小電気ダイポールの場合, 仮想波源は微小磁気ダイポールであるとわかった。一方, 微小磁気ダイポールの場合, 仮想波源は磁気四重極子と微 小電気ダイポールの重ね合わせになることがわかった。

プリント回路のEMI対策に対する関心は高く, 次の 2 件 はクロストークを 2 本線路モデルを用いて解析した報告で ある。森崎慎也, 他”) はプリント回路のクロストークを低 減するため, 2 本の線路の中央に遮蔽導体を配置した遮蔽 効果を解析し, 測定值と比較して低減勃果があることを示 した。古谷親生,他 ${ }^{68)}$ は高速デジタル回路パターンのクロ ストークを解析するため, 結合 2 本線路をモデルに用いた。 ステップ電圧入力時の遠端結合と線路長による遠端結合の 変化を定式化し, 測定と比較した。モデルが単純化しすぎ たためによる誤差なども論議されている。

共平面形線路の曲がりの電磁特性を系統的に調べている 研究に次のものがあった。これらの解析結果は最近, 実用 化に応用されている泫。越地耕二 ${ }^{30)}$ はプリント回路の回路 要素の内伝送線路の直角ベンドの電磁界特性を空間回路網 法によって解析し，反射特性などを示した。澤佐博行,他 ${ }^{42}$ は共平面形線路の円形曲がり部の周波数による電磁界特性 を空間回路網法によって解析し，透過特性などを示した。 篠塚隆，他 ${ }^{57}$ は曲がったプリントパターンからの放射の計 算式を相反定理を用いて，曲がった線路を直線の線路が縦 続接続したものとして導いた。計算值と実測とよく合うの で，基板の損失を検討するのに活用できると期待される。 澤佐博行, 他 ${ }^{58,}$, 62) は共平面線路の曲がり部の高周波数に おける放射特性を調べるために，様々な曲がり角を有する 共平面線路を製作し，放射特性の測定を行って比較した。 久保田達也，他 ${ }^{811}$ はプリント配線板のグランドなどによる 信号伝送特性の劣化を調べた。グランド導体の種々の寸法 のスロットが存在するときの信号伝送特性を測定し，スロ ット部の等価回路パラメータを算出した。スロットがスト リップ線路と直交する場合は信号伝送特性は影響される が, 平行する場合は影響されない。太田義昭, 他95) は角形 曲がりを有する共平面形線路のクロストークを解明するた め, 直線線路のスロットと曲がり線路のスロットの電界を 空間回路網法によって計算した。2 本の共平面形線路が近 いほど結合が強く, 近端結合よりも遠端結合の方が大きい という結論を得た。実用化について, 越地耕二91) は透過特 性を改善するのに内導体オフセットのある曲がり部を使用 することを提案した。

近傍実測磁界分布から波源表面の電流分布を求める数值 的解法を逆問題を解く手法を用いて解いたものに次のもの がある。林昌世 ${ }^{199,26)}$ は漏洩をもつ金属筐体を用いて，その 近傍の実測磁界分布から筐体表面の電流分布を計算し, 漏 洩位置を決めるのが可能と示した。また逆解析で得た表面 電流分布から, 順解析で半径 $3 \mathrm{~m}$ 円筒面の電磁界を予測し 
た ${ }^{78)}$ 。方程式が積分形式で, 電流の項が積分核の一部であ ることから逆解析という。解の数学的吟味が重要であるが, 実用上先験的情報を使うことで信頼性を高めることが可能 である。

波源を仮定して, 差分法によってマクスウェル方程式か ら放射する電磁界を時間領域で計算したのが次の発表であ る。林昌世年) は波源を与えた場合の漏洩電磁界をマクスウ エル方程式から直接数值的に求めた。開口を持つ金属筐体 内部に波源を置いた場合の漏洩電磁界を 2 次元の差分法で 求めて, 過渡解の空間分布を示した。時間軸で解を求めた のは波源に任意の波形を与えられるようにしたためであ る。

大西輝夫, 他 ${ }^{17)}$ は差分法・時間領域計算法を応用し, 電 界と指向性の解析を行った。彼らはFD-TD法を用いてマイ クロストリップアンテナの電界と指向性の解析を行い, FD-TD法を用いたことによって, 3 次元任意曲面の解析で メモリを大幅に節約できた。

シミュレータの核心ともいえる最適配線を設計するアル ゴリズムについて, 次の研究発表があった。佐藤政生 ${ }^{4}$ は LSI自動レイアウト手法として, 非スライス構造でブロッ クの配置に制限のない高集積度で自動化実現可能なBEAR システムを提唱している。中村英博25) はマルチワイヤ配線 板の電気特性の予測に着目し, 必要となる伝搬遅延を代用 電荷法で解析した。実測と併せて, 伝搬遅延は実効比誘電 率に依存することが明らかになった。伝送線路シミュレー 夕に打ける配線の電気特性を予測するには，このような基 礎的解析と実測を多く要する。佐藤政生 ${ }^{38)}$, 栗島亭, 他 ${ }^{32}$ は回路配線の設計にラバーバンドモデルに基づいた逐次配 線手法を用いたグリッドレスルータを考案し，平面配線問 題に適用した結果を示した。この方式は柔軟性に富んで配 線およびレイアウト設計に有望である。勝山芳郎43) はデジ タルプリント配線板による放射ノイズをプリントパターン を細かい導体片に分割し，スペクトル領域法によって計算 した。他のEMIシミュレータに比べて基板の構造に関する 材料定数などパラメータを細かく与えられるので精度が高 いようである。

シミュレータの使い勝手とか効果の評価は大変興味ある 問題でありながら，それらに関する報告を知る機会が少な い。次の論文はその意味で貴重だった。中村英博1),36) は基 板のパターン設計技術は, 高周波の電気特性の測定技術の 他, パターン設計のソフトウエアの開発およびパターンか ら出る電磁界をシミュレーションで把握することが重要と して, 3 次元伝送線路シミュレータの電気特性評価方法に ついて考察を述べた。高橋丈博(2) は市販の電磁放射ノイズ シミュレータPCPEMSIMを用いて, 配線の条件変更時のノ イズの強度変化を調査し, 設計レベルにおけるシミュレー 夕の有効性の評価を行った。金子俊之, 他 ${ }^{15)}$ は容量計算の プログラムCALCAPを用いて, 平面グランドを等価集中定
数回路に置き換え, 配線の違いによる帰路電流の計算を行 つた。柳本太加志 ${ }^{29)}$ は, 特定な回路についてSPICE系のシ ミュレータを用いて回路設計するときの, デバイスの入出 力段のモデル化の問題点を提出した。

シミュレータを利用する設計関係者にとって,「設計完 成までに所要時間が長すぎる」ことと「配線経験に依存す る」ことがネックになっている。次の論文ではそれらにつ いての解決策を提案している。高橋丈博(1) はノイズトラブ ル事例から得られた知識をノイズ対策に活用できるように するため, パソコンで既成のデータベースッールとエキス パートシステム構築ツールを利用して，それぞれノイズガ イダンスシステムとノイズエキスパートシステムの構築を 試みた。樽井勇之, 他 ${ }^{99}$ は伝送線路シミュレータの実用化 に必要と思われる部品配置支援ツールを開発した。次の 2 つの特徴がある。(1) 部品配置段階から配線長を仮定し， 反射ノイズや遅延時間の警告を設計者に知らせる。(2)設 計段階でノイズに関する情報をデータベース化し，効率を 向上する。高橋丈博, 他 ${ }^{76)}$ はプリント配線板上の線路から の放射ノイズを等価回路網法を用いて計算するッールを開 発した。配線を等価集中定数線路に置き換える等価回路網 法は他の放射ノイズシミュレータに比べて, 基板の損失お よび部品モデル化の扱いが容易になった利点がある。

シミュレータを開発者から解説が聞けるというのは，な かなか貴重な機会であった。松井則夫21),27) は回路設計で配 線・接続部でのノイズを考慮したシミュレーション・シス テムを開発した。回路シミュレータContec SPICEとプリン 卜回路板CADであるHENRYとMETALを結合して，大規 模・高速・高密度の回路設計を可能にした。池田三喜夫, 他 ${ }^{11}$ はQuad Design Technology社開発の高速デジタル回路 設計用ツールであるゲート入出力間の遅延時間を解析する MOTIVEを紹介した。その他, 伝送線路の放射・遅延を解 析するTLC, PDQ, およびクロストークノイズと損失も考 慮して伝送線路効果を解析するXTKの紹介を行った。前田 真一52) はCadence社開発の伝送線路シミュレータSIAとプリ ント配線板の設計ツールであるCBDの紹介を行った。CBD （Correct by design）は必要なルールを入力すると自動的に 訂正する利点を持つ。

\section{2 測定理論関連}

プリント配線板（PWB）の電磁特性測定に関しては, 信号の高速化に伴いプリント配線板上の配線の伝送特性や 反射・クロストークの測定と, プリント配線板からの不要 電磁波の放射量の測定一いわゆる EMI測定一，および回路 の誤動作に関連したイミュニティ測定が行われている。

堀田幸雄による「EMCの測定と対策」についての解説 ${ }^{49)}$ が参考になる。なお， EMC（電磁環境適合性）はEMI（電 磁妨害）とEMS（電磁感受性）の両方を含む。EMSはイミ ュニティ（耐性）と対になる概念で，イミュニティの大き い機器はEMSは小さいことになる。 
まず，伝送特性に関しては，高周波電磁特性を知ること の重要性が認識され, CADとの連動やシミュレーションの 必要性が多く語られるようになった(1),27),29),36),43),72),76),103)。実 際に, 伝送線路シミュレータの開発指針を得ることを目的 にしてマルチワイヤ配線板の伝搬遅延が測定され, 代用電 荷法によるシミュレーション結果との比較が報告された ${ }^{25)}$ 。 また, 多層基板の比誘電率, 特性インピーダンス, 信号伝 搬遅延時間の測定とシミュレーションとの比較も行われて いる ${ }^{\mathrm{B} 1)}$ 。MCMの電気特性に関しても，絶縁層にポリイミ ドを用いた銅配線MCMについて特性インピーダンスと $1 \mathrm{GHz}$ パルス信号の伝送特性が評価されている22)。

さらに，ディジタルプリント配線板のノイズに関連して， 電圧波形やグランドノイズ, 反射ノイズ, クロストークな どが，放射ノイズと共に測定評価されている24),44)。その際 に, ディジタルICの種類ごとの特性を把握して, 設計やノ イズ対策をすることが必要であるとの主張が増えてきてい る24,44),45)。出力の立ち上がり時間や伝搬遅延時間, IC種ご とのノイズスペクトルが測定されている50)。

最近は設計の現場に伝送線路シミュレータを導入して高 速回路の設計支援を行う場合も増えており，これを活用す るための波形測定やデータの蓄積も多く行われているはず である。これらの測定手法や結果について，もっと数多く の発表が行われ, これを活用した新しい設計法が共通の財 産として発達することが望まれる。

次に, プリント配線板からの不要電磁波放射の測定に関 しては, かつては試作品のEMI評価として規格に従った測 定が行われてきた。しかし最近はもっと積極的に, EMIレ ベルの低いプリント配線板の設計法を検討したり, EMI予 測シミュレータの開発や, EMI対策部品の効果を定量化す ることを目的として, 特別の評価用基板を試作してEMI測 定を行う例が増えている24),34),45),50),64),100)。その結果, 例えば 多層基板に扎いて表面層の誘電体厚さを薄くすることが放 射低減に寄与する ${ }^{64)}$ などの結果が得られている。

また, オープンサイトや電波無響室での大がかりな測定 に代わって, 近傍電磁界を測定してEMIレベルの評価を行 い，これによりEMI対策を行うことについてもかなり検討 されている。規格に定められたEMI測定サイトにおける測 定と簡易電波暗室における測定およびEMSCAN（近傍磁 界を簡易測定する市販の装置) による測定の相関について

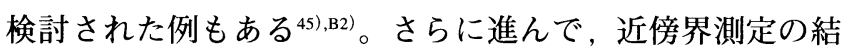
果を解析することにより電子機器筐体上のノイズ電流分布 を求め, これから遠方への放射を求めようとする試みもあ る $^{19), 26) 。}$

この近傍電磁界の測定については装置も工夫されてきて おり，工業的な有用性を考え，測定しているプリント配線 板のイメージをビデオカメラで撮影し，コンピュータ画面 上で磁界分布に重ね合わせるようにしたものが開発されて いる ${ }^{85)}$ 。
電磁放射に関して，IC種ごとの特性の違いとの関係が評 価されている。CMOSディジタルICのスイッチング時間の 負荷容量依存性と放射電磁雑音レベルについて測定した例 や落）さらに進んで同一型番のICの電気特性のメ一力間， ロット間のばらつきによる放射電磁雑音レベル差を評価し た例もある ${ }^{\mathrm{B})}$ 。また，パッケージの違いによる放射電磁雑 音レベルの差も実測評価されている ${ }^{\mathrm{B} 5)}$ 。実装上の問題に関 して, ICの電源・グランド系の対策が必要であること, ダ ンピング抵抗の効果について述べられている ${ }^{45)}$

イミュニティに関しては，TEMセルを用いてパソコンの

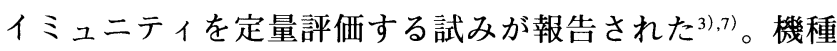
ごとに特定の周波数でイミュニティが低下するデータが示 されており，興味深い。ちなみに，テスト用基板を用いて ディジタル回路の誤動作機構を解明しようとする試みもあ $り^{88), \mathrm{B} 6)}$, やはり特定周波数でのイミュニティ劣化の可能性 が示されている。

先に近傍電磁界の測定について述べたが, 逆に近傍磁界 をプリント配線板に印加することにより，回路の局所的な イミュニティを調べるという報告があり興味深い90)。2つ のループアンテナを対向させてプリント配線板を挟み込む ことにより特定方向の磁界の印加を可能にしている。また， 新しいタイプのイミュニティ測定システムとして，ある地 点でのノイズ環境を測定して記録し，それと同じノイズ環 境を電波暗室内に再現するという研究がある77).98)。野外な どのノイズ環境での機器動作試験は困難な場合が多く, こ のようなシステムによって安定した環境で等価な試験が行 える。

回路の誤動作に関連して, Tape Carrier Packageの CMOS LSIの同時スイッチングノイズによる内部F/Fの反転誤動作 が評価された ${ }^{10)}$ 。入出力ピンの配置により結果が大きく違 うこと, 基板上のパスコンの有無は結果に影響せず, LSI パッケージでのノイズ対策が重要であることが示された。

機器レベルのノイズ問題を扱ったものとしては次のよう な報告がある。電磁調理器のラジオ放送への干涉が検討さ れている ${ }^{53)}$ 。電磁調理器は主に漏洩磁界が大きいため, 距 離を離すのが最も効果的であるとしている。また, 自動車 のシートによって発生する静電気の評価試験法に関する報 告 ${ }^{89)}$ がある。自動車は様々なノイズ源をかかえる上に安全 性が非常に重視されるものだけに，ノイズ問題には慎重に 取り組む必要がある。

以上のような測定を行う上で, 測定方法の整備や様々な 工夫が必要になってくる。最近話題となっているイミュニ ティの測定場に関する研究が行われている ${ }^{54)}$ 。放射イミュ ニティの測定には電界強度がある範囲(周波数，場所)で一 定になるように調整された測定場が必要である。ここでは， この条件を満たすために金属フェンスを用いた方法が提案 されている。次に，放射ノイズを測定する装置として久か せないのはアンテナであるが，その複素アンテナファクタ 
を 3 アンテナ法により測定する方法について報告されてい

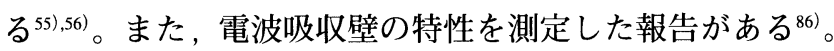
抵抗被膜を格子状に配置し，その間隔，深さ，抵抗值によ る吸収特性を明らかにした。

\section{EMI対策の実践}

EMI対策はローパスフィルタやコモンモードチョークな どの部品を使用する他に，シールドのために種々の材料を 使用したり，回路設計，実装設計による方法など多岐にわ たる。ここでは, EMI対策を部品, 材料, 回路に分類し, それぞれの技術について解説する。理想的なEMI対策はこ れらの技術が効率よく組み合わされて実現する。

\section{1 部品による対策関連}

電子機器から放射するEMIは機器ごとに特徴を有してい る。

スイッチング電源は多くの電子機器の共通のEMI放射源 であるが, 出口らはスイッチング電源特有のEMI 対策をま とめた ${ }^{16)}$ 。また，種々の電子機器のEMI対策に共通する手 法をまとめた, 越地による「電子機器のEMC設計・対策」 は, EMI対策の実際面と理論面が扱われている点で参考に なる ${ }^{47)}$ 。

ここではこうしたEMI対策のなかで部品, とりわけEMI フィルタを使用した対策について述べる。

ノイズフィルタは一般にEMIフィルタとよばれ, 通信用 など信号伝送回路に使用される低域通過型フィルタと多く の点で異なっている。

フィルタ回路の基本区間はインダクタンスとキャパシタ ンスによって構成され, 公称インピーダンス $\mathrm{R}(\Omega)$, 遮断 周波数 $\omega_{0}$ を定め各々の素子を決定する。しかしながら EMIフィルタの場合, 回路構成はほぼ同一であるものの， 公称インピーダンスで整合されて使用されることはなく， 特に電源ラインに挿入されるEMIフィルタの場合, 通常, 挿入損失量は $50 \Omega$ 系で測定されるのに対し, 電源側のイン ピーダンスは場所や時間で様々に変化し, 負荷側のインピ 一ダンスも装置によって異なり, スイッチング電源を使用 している例では，数十 $\mathrm{k} \Omega$ に達することが報告されてい

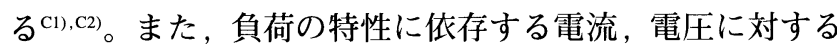
レベル特性も要求される。また, 通信用フィルタでは通過 帯域での伝搬特性, 位相特性およびカットオフ領域でのシ ヤープさなどが要求されるが, EMIフィルタにおいては阻 止領域での減衰量や挿入損失量と周波数軸上での広帯域性 が要求され, したがって, これらの相違点からもわかるよ うに設計方法や評価の方法に各々相違点がある。

ノイズフィルタを設計したり, 利用する場合に, フィル タを挿入しようとする位置でのノイズの伝送モードに適し た設計や選択をする必要がある。伝送モードは線間電圧と して負荷電圧（または電流）に重畳する形で伝送するノー マルモードと接地系が伝送に寄与するコモンモードに分け
ることができることはよく知られている。ノイズは線間で 発生するのでノーマルモードであるが発生源から離れるに したがって接地系の影響でコモンモードへのモード変換が おき, 電源線や信号線をアンテナとした放射性のノイズに なるなど, 結果的には双方のモードが混在していると考え なければならない。したがって, EMIフィルタとしてはノ ーマルモード抢よびコモンモードに対して低域通過型フィ ルタの回路構成をもつものが一般的である。

ノーマルモード成分に対してはノーマルモードチョーク とXコンとよばれる対線間のコンデンサからなる回路と, コモンモード成分に対してはコモンモードチョークとYコ ンとよばれる対接地間コンデンサからなる回路が複合した 低域通過型フィルタ構成がEMIフィルタの基本回路である が, 電子機器やフィルタの取り付け環境によってノーマル モードが問題にならなかったり, 逆にノーマルモードだけ が問題になるケースを想定し, この基本回路は様々な形に アレンジされる。

EMIフィルタにおいて重要なのは通過帯域の伝送特性や カットオフ周波数, 損失特性の立ち上がりのシャープさな どよりも, むしろ阻止帯域の広さである。この意味でEMI フィルタは低域通過型フィルタ（ローパスフィルタ）では あるが帯域阻止型フィルタ（バンドエリミネータ）でもあ り，阻止帯域の広带域性を評価しなければならない。EMI フィルタの広帯域性能を決定する要因は低周波領域ではイ ンダクタンスLとコンデンサ容量の積であり, カットオフ 周波数から一段当たり $6 \mathrm{~dB} / \mathrm{oct} の$ 割合で損失量が増加し, 高周波領域ではインダクタのもつキャパシタンスおよびキ ヤパシタのもつインダクタンスで決定される。

したがって，この帯域ではEMIフィルタの実装方法によ り挿入損失特性が大きく左右される。またインダクタンス 素子はEMIの伝送モードによりノーマルモード素子とコモ ンモード素子に分けられる。ノーマルモード素子では電子 機器の負荷電流がそのまま流入するために飽和磁束の高い 純鉄やパーマロイなどの圧粉磁心（ダストコア）が多く用 いられる。一般に圧粉磁心は体積固有抵抗が高く，このた めに透磁率の周波数特性が純鉄はもちろんケイ素鋼やパー マロイに比べても優れている。また特に鉄の圧粉磁心の場 合, ヒステリシスロスが大きく, カットオフ周波数付近で の負の挿入損失 (挿入利得) の発生を軽减するため, イン パルス性のノイズが入力したときのダンピング特性に優れ ており，サイリスタのノイズ防止部品として古くから用い られてきた ${ }^{\mathrm{C} 3)}$ 。コモンモード用インダクタンス素子にはマ ンガン系またはニッケル系のフェライト磁心が用いられ る。フェライト磁心は透磁率の大きさ, その周波数特性な どの点で圧粉磁心よりも数段優れているが, 飽和磁界が極 端に小さいため, 直接, 負荷電流を流すような使い方がで きない。コモンモード用インダクタンス素子の場合, 前述 したごとくコモンモード成分，すなわち接地に流れ込む電 
流に対してインダクタンス素子となればよいので, 負荷電 流による磁心内部の磁界を相殺し，電流の影響を受けない バイファイラ巻きで使用している。EMIフィルタの良否を 決定するのは挿入損失特性である。挿入損失を測定する方 法として, JIS-C-6904PMIL-STD-220Aに定められた 方法を用いるのが一般的であるが，次の事情で多くの問題 点も含んでいる。

(1) 測定信号が $100 \mathrm{dBuV}(0.1 \mathrm{~V})$ と微小であること。

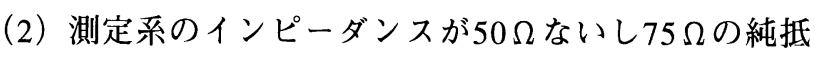
抗であること。

（3）定格負荷電流が流れていない。

（4）定格電圧が印加されていない。

などの点で, EMIフィルタの実装環境とはだいぶ異なって いる。このためカタログなどで表示されている損失特性と 実装特性との間に食い違いを生ずることがある。現実には 定格電流や定格電圧が印加されるとインダクタンス素子は 電流により，またキャパシタンス素子は電圧により初期值 と異なったレべル特性をもち, EMIフィルタから見たとき の電源側と電子機器側のインピーダンスは複雑な複素イン ピーダンスを示し, しかも刻々と変化していると考えなけ ればならない。また, 電源に数 $\mathrm{kV}$ のサージが誘起した場 合にも対応しなければならない。

これらの点から，できるだけ実動状態に近い方法での評 価が必要である。

堀田らは, EMIフィルタにあらかじめ定格電圧を通電し た状態で入力に高電圧パルスを加え, 出力側の応答を見る 方法を開発した ${ }^{(4)}$ 。ここではCISPR Publ. 16などで定めら れている擬似電源回路網を使用している(5)。これにより前 述した問題の大半は解決し, より実装状態に近い特性を観 測することができる。より高性能のEMIフィルタ開発のた めに, 種々の方法が考案されている。CISPR Publ. 17「受 動形無線妨害波阻止フィルタおよび抑圧素子の特性測定 法」では, 標準試験法, 最悪条件法, 実用状態による試験 法, 擬似装置による試験法の 4 種類の測定法を提案してい る(6)。これらのなかで特に興味ある方法は最悪条件法で, これは最悪条件法と近似測定法に分けられ, さらに最悪条 件法はインピーダンス変化法と準解析法に分けられてい る。準解析法はインピーダンスの実測值から最小の減衰量 を算出しようとするもので, フィルタのテブナンインピー ダンス打よび伝達インピーダンスを定義し, これらの測定 值から得られる最小電圧減衰量の $\alpha \mathrm{V}_{\min }$ (入力電圧と出力 電圧の比）は，

$$
\begin{gathered}
\alpha \mathrm{V}_{\min }=20 \log 10\left(\mathrm{Z}_{0} \times \mathrm{g}_{0}\right) \\
\text { ただし }, \mathrm{g}_{0}=\frac{\mathrm{R}}{\mathrm{R}^{2}+\mathrm{X}^{2}} \text { ジーメンス }
\end{gathered}
$$

Z 0 は伝達インピーダンスの絶対值で, $\mathrm{g}$ oはテブナンインピ 一ダンス $\mathrm{R}+\mathrm{jX}$ より求める。

この方法では, EMIフィルタのテブナンィンピーダンス
と負荷回路のインピーダンスがコンジュゲートにあり, 減 衰量が最小となるため, 最悪条件下での測定であるといえ るが, 高周波における電圧測定, 電流測定を伴うので困難 さが残るとともに測定治具による測定の再現性の問題など 検討すべき課題は多い。また同様にCISPR Publ. 17に述べ られている近似測定法では, 電源-EMIフィルタ負荷のイ ンピーダンスの不整合の影響をみるために，広帯域トラン スを使用した $0.1 \Omega / 100 \Omega$ システムを提案している。

この方法は, インピーダンスの不整合によりカットオフ 周波数で負の挿入損失量, すなわち挿入利得が起こり, 不 要なリンギングを起こす可能性があるため，不整合環境を 作り，より悪い環境での伝送特性を測定する方法である。

このように様々な試験方法が検討されているがCISPR Publ.17でも提案している「実用状態による試験法」が現在 のところ最良の方法といえよう。

どのように高性能に設計されたEMIフィルタでも，使用 方法によってはまったく効果が得られなかったり, 逆にシ ステムの性能が劣化する例が報告されている(7)。電源ケー ブルの筐体の入口からEMIフィルタまでの距離が長かった り, EMIフィルタの入力側にヒューズボックス，メインス イッチなざが配線されていると, 電源線, EMIフィルタ, 筐体を流れるループ電流による磁束が他の回路板や回路部 品と結合して, EMIフィルタをバイパスする結合ができ， フィルタ効果を劣化させる可能性を生ずる。したがって， フィルタの入力と出力が筐体によって遮蔽されるようレイ アウトを検討すべきである。また，EMIフィルタの入出力 は分離しなければならない。入出力線が束ねられる場合と インレットソケットにフィルタが封入され，分離が十分に 行われている場合との比較では，1MHzあたりにおいて $15 \mathrm{~dB}$ 程度の挿入損失の差異が見られ，さらに高い周波数 ではこの傾向は増すことが報告されている(7)。

EMIフィルタの接地点と筐体の接地点の位置が大きく異 なると, EMIフィルタのリーク電流およびノイズ電流が筐 体に流れることになる。これは筐体に電流を流してはなら ないというノイズ対策の原則を犯すことになり，様々な不 具合を誘発する。例えば，筐体輻射の原因になるし，接地 電位が摇さぶられ，システムの動作が不安定になる，など である。このような現象は電子装置が大型になるほど顕著 に現れる。

EMIフィルタの接地リードや, パターンの微小なインダ クタンスが高周波領域の挿入損失特性を劣化させる例も示 されている。この例ではAWG\#14を $5 \mathrm{~cm}$ の長さにして接地 リードとして使用した場合の劣化の程度を示しているが， $10 \mathrm{MHz}$ で30dBの差異があることが報告されている(7)。

EMIフィルタを回路板上でディスクリートに組んでパタ ーンを使って接地するような場合は，さらに大幅な劣化が 起きている可能性がある。

電源におけるEMIフィルタに対して，データラインに使 
用するフィルタをデータラインフィルタとよぶ。デジタル 信号を取り扱ったデータラインでは，ビーズインダクタや 前述の低域通過型フィルタを使用する場合，伝送波形の立 ち上がり，立ち下がりの特性が少なからず影響を受けるの で注意を要する。周波数帯域が限られているアナログ信号 ラインやマネージメントバスのように伝送波形の品質があ まり問題にされないデータライン，不必要にパルスの立ち 上がりが早い部分，パターンなどのインダクタンスにより リンギングが発生しているようなラインにはビーズインダ クタや $\mathrm{T}$ 型低域通過型フィルタを使用し, 高速プリンタや モニタなどに対してはEMIフィルタのコモンモードィンダ クタンス素子と同様の動作原理をもつ素子を使用する。こ のタイプのフィルタはカットオフ周波数, チャンネル数, 実装構造などによって様々な形のものが商品化されてお り，ユーザの選択の自由度は広い。通常インダクタ素子に は損失の大きいフェライトビーズ，キャパシタンス素子に はセラミックのチップをそれぞれ使用したものが多く，こ のようなフィルタをコネクタに組み込んだタイプではセラ ミックの貫通型コンデンサを利用するなどの工夫もなされ ている。同様の回路で構成された分布定数型のフィルタで は, 絶縁膜を挟んだ導電体リボンからなる構造で, 内部の 複雑な共振から通常のフィルタより広帯域に減衰性能を有 する分布定数型フィルタも開発されている。データライン が高速の信号を取り扱っており, 前述の低域通過型フィル タの適用ができない場合, 電源ラインでのコモンモードイ ンダクタンス素子と同様の考え方に基づく素子を適用す る。

個々のラインにフェライトビーズを挿入した場合と 1 つ のフェライトビーズにデータラインをすべて貫通させた場 合の違いについて比較すると，それぞれのラインに挿入し た場合，ドライバ側から見たレシーバ側のインピーダンス はインダクタンスの影響を受けるが, 他方の場合は負荷イ ンピーダンスは変化しないがコモンモードに対してはイン ピーダンス素子となる。このことは，伝送信号に影響を与 えないでコモンモード電流を抑制する効果をもつことを意 味している。

最近では, 電子機器の小型化や高密度実装化に伴い, 前 述のデータラインフィルタやインダクタも表面実装用のも のでハーフピッチで20ラインまで対応が可能なチップが開 発され, 今後, 種々のEMI対策用素子が表面実装型化する ことが期待される。

\section{2 材料による対策関連}

電子機器のEMI対策は, システム設計・筐体設計・回路 設計・使用部品の選定・配線板の材質および構造選定・配 線板の設計ルール設定等，多岐にわたる。

高度情報社会の発展が著しい昨今は，プリント配線板に 要求される課題として, 次に列挙する項目をクリアさせる 必要がある。
（1）電子部品の高密度実装とパターンの細密化

（2）信号伝搬速度の高速化と信号の立ち上がり時間・立 ち下がり時間の短縮

（3）移動体通信に代表されるGHz領域への高周波対応技 術

（4）EMI規制值をクリアすると共に外来ノイズに対する イミュニティの確保

これらの課題を解決するには, プリント配線板の電気特 性である次の事項を明確にして, 要求された仕様に適合し たプリント配線板を設計・製造する技術を確立することで ある。すなわち, 導体抵抗(R), 表皮抵抗 (Rsk), 基材の比 誘電率 $\left(\varepsilon_{\mathrm{r}}\right)$, 基材の誘電正接 $(\tan \delta)$, 導体のインダクタン ス $(\mathrm{L})$, 線路の特性インピーダンス $\left(\mathrm{Z}_{0}\right)$, クロストーク結合 係数 $(\mathrm{K})$ 等を仕様に適合させることである。

本稿では, 電磁特性研究会活動の中で, 実践EMI対策と して，材料選定を中心に研究発表されたテーマについて， その論旨の要約を紹介する。

諸橋欣一8) は, プリント配線板のノイズ対策の動向とし て, 当面のノイズ対策は場当たり的なカットアンドトライ 法であるが，次第にノイズ対策技術が向上し，配線板CAD とノイズシミュレータを結合させた配線板設計法が確立す ることを予測している。

また, 低ノイズ配線板の設計の要点は, 第 1 が部品配置, 第 2 が回路ブロックごとの低インピーダンスグランド，第 3 がSMD利用の高密度最短配線技術の確立であるとしてい る。

須藤俊夫 ${ }^{22)}$ は, 高密度実装・高速信号処理の方法として MCMの有効性を確認した。銅／ポリイミド薄膜配線板を 製作し，その特性インピーダンス(メッシュグランドにて) と $1 \mathrm{GHz}$ までの伝送特性を測定。これらのデータを基に， 32 ビットRISCプロセッサ, SRAMとラッチICを搭載した MCM基板を製作した。この結果RISCプロセッサの今後の 高速化に対し, 本方式のMCMは十分に機能を果たすこと を確認した。

山本裕三 ${ }^{23)}$ は, 金属の腐食とポリマーの帯電現象につい て論じている。腐食の大部分は水の介在で発生し, 局部電 池の形成が腐食を進行させる。腐食の防止策の一方法とし て, 不動態膜の形成という手段もある。ポリマーの帯電防 止には, 絶縁物の体積固有抵抗を $10^{12} \Omega \mathrm{cm}$ 以下にすること, または, 界面活性剤を用い, 表面に水を吸着させ, 表面固 有抵抗を低下させることの 2 方法が一般的である。

松永茂樹 ${ }^{24)}$ は, プリント配線板のグランド電位に接続し た銅ペースト層がEMI対策に大きい効果が発揮できること を実験を主体に報告している。銅ペースト層形成でEMI対 策が可能である理由は, PWBのグランドインピーダンス の低減, 信号線の特性インピーダンスの低減, 信号線の対 地間ストレーキャパシタンス増加によるノイズ還流効果等 によるとしている。 
中村英博 ${ }^{25)}$ は，マルチワイヤ配線板の伝搬時間（Td） を代用電荷法によるシミュレーションと実測值の比較を行 つた。絶縁物体内にワイヤを埋め込み, その埋め込み深さ と実効比誘電率の関係をグリーン関数を用いて解いた。こ の関係からTdおよびZ。を計算した。このシミュレーション 結果と実測值はよく一致した。実際の配線板は単純なマイ クロストリップやストリップ構造とはいえず, 信号線の交 差等がある。これらの3次元解析の必要性を提言している。

福川弘 ${ }^{35)}$ は, 通常使用されるガラスエポキシ多層銅張積 層板の電気特性を測定した。その中で, 絶縁物の比誘電率, 信号線の静電容量, 信号線のインダクタンスは周波数依存 性が大きい。これに対して, 特性インピーダンスはマイク ロストリップ線路および，ストリップ線路共に周波数依存 性が小さく，Z0に関する定義式・近似式・TDR法は共によ く一致することを確認した。

青木正光 ${ }^{40)}$ は, 最近の電子機器の動向から銅張積層板の 今後について論じている。その主なものは, 軽薄短小の八 ンディ機器用の積層板は, 一層当たりの基材厚さは $0.1 \mathrm{~mm}$ の時代に突入, 特性インピーダンス等の電気特性の均質化 のため積層板の加工精度が㛜しく要求される。この他, 基 材の高周波特性の改良, 伝搬遅延時間の短縮, IVHやBVH を利用しての高密度実装化等, 課題は多いと論じている。

諸橋欣一 ${ }^{65)}$ は, プリント配線板の伝送特性の改善につい て, マイクロストリップ, ストリップ, 共平面, 共平面ス トリップの4種の線路を作り，伝送損失 $(10 \mathrm{kHz} \sim 500 \mathrm{MHz})$ と放射ノイズレベルを測定評価した。その結果, 伝送損失 では共平面回路が損失が少なく, 放射ノイズテストでは共 平面とマイクロストリップ構造の両面板が良好な成績を収 め, 実基板では本構造を採用してEMIフィルタを18個削除 した。

森元昌平70) は，ハイブリッドIC等に使用できるディップ コート用低粘度銅ペーストを開発した。その施工法は, 八 イブリッドICに絶縁物を全面コーティングし, その表面に ディップにより銅ペースト層を構成した。なお，銅ペース トは 1 点または数点GNDピンと接続する方式である。こ の方式のEMI対策効果は, $50 \mathrm{MHz}$ 以下の周波数領域で約 $5 \mathrm{~dB}, 50 \mathrm{MHz}$ 以上の周波数領域で $10 \mathrm{~dB}$ 程度である。

伊藤健一 ${ }^{73)}$ は, PCBのEMI対策法として 3つの提言をし ている。第 1 はべタVとべタアースの効用, 第 2 は高周波 損失の多い基板の採用, 第 3 はスナバー回路の採用に分類 できる。

第 1 の提言は, グランドインピーダンスの低減には, ベ タアースプラスベタV（Vcc側）の構成にして, ベタVとべ タアースを対向させて, かつ両者を等面積にする。この方 法で両者間のキャパシタンスが増加し, グランドインピー ダンスが低減できることを示した。

第 2 の提言は, 安価な紙フェノールや, 紙エポキシは $\tan \delta$ が大きい。放射ノイズレベルを同一パターンの P W
Bで実測した結果，上記材質のものはCEM- 3 材に比べて5 〜9 dB放射ノイズレベルを低減できる。

第 3 の提言は，ノイズを吸収できるものは抵抗である。 たとえばバイパスコンデンサにはL分を含む。大容量コン デンサはLが大きい。大小 2 個のコンデンサを並列接続す るとLは低減できるが, 反共振が発生する。反共振点でイ ンピーダンスが増加する。この悪影響を軽減する最良の方 法はコンデンサと直列に小さい抵抗を接続し，スナバー回 路を構成することである。

森元昌平 ${ }^{74)}$ は，銅ペーストによるEMC対策の動向とし て, 通常のリジッド配線板から FPCへの応用, 最近では八 イブリッドICへの銅ペーストコーティングと次第に応用分 野が広がり，それぞれの応用例でEMI対策効果を示してい る。特にディジタル・アナログ基板の対策ではアナログ信 号のSN比の向上, メモリカードではイミュニティの向上, FPC部からの放射低減等に大きい効果を発揮していること が報告されている。

\section{3 回路設計による対策関連}

近年, 情報伝達のスピード化の要求は電子回路を従来以 上に高速化することになり，したがって，これら電子機器 の発展と普及はますます, 電磁環境対策 (EMC対策) が 重要な課題になっている現在であり, 電子回路に対する電 磁波障害対策 (EMI対策) の動向は, 概略次のように分類 でき，それぞれについて研究され改善対策が考えられてい る。

（1）ノイズの発生源である電子回路の動作状態の改善

（2）信号が伝達される伝送路の構成と伝搬形態の改善

（3）電子回路を安定に動作させる電源やグランド回路

（4）回路を構成する部品の実装形態と実装方法の改善

（5）プリント配線板(PWB)の基材や層構成と回路パター ン形成の改善方法

本研究会に打いても回路に関連する実践的なEMI対策技 術の動向は公開研究会および運営委員研究会を含めて過去 4 年間に106件中で3割以上に及ぶ34事例が講演発表され た。その概要を紹介すれば次のような内容である。

高周波回路(GHz帯周波数)では, 衛星放送 (BS) や衛星通 信用アンテナなどの回路において高誘電率基材を利用した 衛星通信用多層プリントアンテナの改善方法と小型化によ

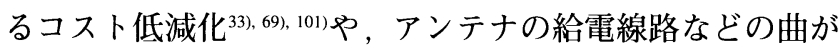
り線路における特性解析や改善方法 ${ }^{42)}$, 58)の 5 件が講演発表 された。また移動体通信関係では携帯用電話機の 3 次元実 装技術による電気的特性 ${ }^{97}$ は特に, 各IC回路間の干渉に対 するアイソレーション技術が注目される。

一方, デジタル回路の高速化に関連する事例ではLSIC の高集積化に対する回路実装のパッケージング方法とその 特性改善対策10), 22), 96)や高速デジタル回路の伝送特性と改善 対策 ${ }^{68)}$ の 4 件が講演, 論議されている。

最近では実践的な回路設計の早期EMI対策の手法として 
コンピュータを利用したシミュレーション技術による検証 が定着しつつあり，電子回路の高速化と共に早期EMI対策 として不可欠なものになってきている。この応用例として 高速デジタル回路設計の検証 ${ }^{51)}$ PTDR法によるインターコ ネクションの電気的特性の検証 ${ }^{104)}$ および, 伝送線路の八 イズシミュレータ211,27,72)について 5 件の紹介説明が行われ， プリント配線板(PWB)の回路設計時点でEMI対策がCADと 連動したシミュレーション技術によって，短期間にその概 略の検証が可能になってきた。

PWBの伝送線路に関するノイズ対策としてPWBのノイ ズ対策技術5),8) ではその対策方法や技術動向について解説

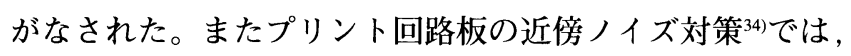
信号系のバスラインやクロックラインの放射ノイズに関連 して問題点を提起した。

マイクロストリップ線路ではグランド導体のスロットに 対する信号伝送特性と改善方法 ${ }^{81)}$ や多層プリント回路板の グランド面のスリットによる放射ノイズの低減法 ${ }^{82}$ などは 信号とリターングランドに関する改善対策方法であり, ま たグランド導体の強化対策による放射ノイズの低減方法と して銅ペースト処理したプリント回路板も注目され，放射 ノイズを低減するデジタルPWBの設計 ${ }^{24), 83)}$ や銅ペースト処 理したSW電源回路のEMI対策 ${ }^{16)}$ が講演, 論議された。一 般にPWBのグランドリターン回路は常に有限のインピー ダンスが存在し，それが無視できるかどうかの問題で，そ の影響力は大きく関係してくるのでPWBのEMI対策として 重要な課題となる。その他に電源グランド回路の電流ルー

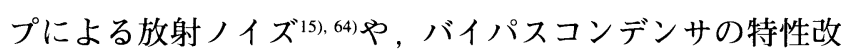
善84) の提案もなされている。

ノイズ対策と密接に関係する P W B の部品実装レイアウ ト設計関連では伝送線路シミュレータによるレイアウト設 計 ${ }^{29)}$ と放射ノイズを考慮した部品配置支援ツール ${ }^{59)}$ やバ 一バンド表現によるグリッドレス・レイアウトシステムム ${ }^{38)}$ およびラバーバンド表現によるグリッドレス・ルータ ${ }^{32)}$ の 4 事例が提唱された。

一方では電子機器や電子回路が電磁波妨害（EMS対策） を受ける場合もEMI対策と同様に電子回路のノイズ排除能 力が重要な課題になってくるわけで, この研究会において も落雷による家電機器の障害 ${ }^{2}$ や雷現象と電子機器の障害6) 例と近年の電子機器の筐体 (キャビネット) や機構部品の プラスチック化による製品と電子回路に対する静電気の発 生と障害 ${ }^{31)}$ のメカニズムと実際の事例について研究紹介が あり, PWB回路設計における静電気対策技術として大変 参考になるものと思われる, また実際のEMC測定と対策 方法 ${ }^{49)}$ および機器のEMC ${ }^{75)}$ やTEMセルによるパソコンの イミュニティ測定と評価 ${ }^{7)}$ につて解説が行われ, 最近の $\mathrm{EMC}$ 早期対策の動向は大がかりなオープンサイトや電波 暗室などの設備を利用せずに, 簡便なベンチマーク , テス トによる早期対策の評価方法が検討されつつあり, 今後の
展開が期待されている。

電磁環境対策は, 電磁波利用の多様化と共に国際的な見 地からより良い電磁環境改善が必要であり, 今後共に大き

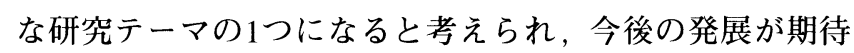
されるところである。

\section{4. 长の他の研究}

電磁特性研究では広い分野の研究がされており, 以下に 成果を述べる。

（1）EMC，EMIの理論から対策までを前節で研究してい るが, 発生している雑音がそのまま情報の漏れである ことも事実である。瀬戸信二 ${ }^{66)}$ はパソコンからの雑音 が電磁波の放射や伝導放射により外部に漏れているこ とを指摘, さらにこの雑音を受信してほぼ完全な情報 の再現ができることを示した。妨害波としての側面だ けでなく, 情報管理の面でもこうした不要放射の低減 がますます重要になっているといえる。

（2）電磁特性を論じていくなかで基本的な概念として, 扱う信号の遅延を論じる際の信号の速さに関して, 周 英明 ${ }^{13)}$ は波動の伝搬を「位相速度」「波頭速度」「信号 速度」「群速度」「エネルギ伝送速度」の 5 通りに分け， 解説を加えた。

（3）静電気による障害は各種発生するが, そのうちの電 磁ノイズによる障害も対策の難しい問題である。電気 回路の絶縁性と相反するように静電気が発生しやすい 環境が整う。帯電した電荷の放電に際しては，ノイズ の発生や破壊を伴うことが多々ある。山本裕三23) は電 気絶縁性に優れているポリマーの接触帯電機構につい て, ポリマー表面にも電子の授受を可能にする電子密 度の高い領域が存在すると想定したDukeらのモデル を解説し, 帯電防止についても防止技術とその機構に ついて報告した。また, 村田雄司 ${ }^{31)}$ は静電気障害の事 例を分析しそのメカニズムを論じた。また帯電と放電 の機構を解説し, その抑制について事例を上げて報告 した。

（4）電磁特性の改善や対策等で金属を扱う場合が多々あ るが, 金属表面の酸化現象をわかりやすく解説したの が山本裕三 ${ }^{23)}$ である。ここでは金属面の酸化の進行, すなわち腐食について, 水が存在しない乾食と水が存 在する湿食について, その機構を解説した。

\section{5.あとがき}

以上, 本学会電磁特性研究会における, 過去 4 年間のプ リント回路の電磁気学的な視点に立った研究の進展につい て紹介した。本稿が, 学会員諸氏のEMC関連の研究や仕 事において，かならずや一助になるものと信じている。電 磁特性研究会の活動は, これで終わったわけではなく, 今 後も継続される。研究会等の講演やディスカッション, ま 
たWGにおける活動等にできるだけ多くの方々が参加され ることを希望し, 回路実装技術のなお一層の発展を期待す る次第である。

(1995.4.28－受理)

\section{文献}

四電磁特性研究会発表関連

※引用文献に次の略記号を使う。

$\lceil\mathrm{B}-\mathrm{n}$ 委報」: プリント回路学会電磁特性研究会, 第 $\mathrm{n}$ 回 (平成3 4年度) 運営委員会

$\lceil\mathrm{C}-\mathrm{n}$ 委報」: プリント回路学会電磁特性研究会, 第 $\mathrm{n}$ 回 (平成5 6年度) 運営委員会

「研報B」: プリント回路学会電磁特性研究会活動報告書 (平成3 4 年度)

$\lceil$ 研報C」: 回路実装学会*電磁特性研究会活動報告書 (平成 5 6年度)

「研論」: プリント回路学会電磁特性研究会公開研究会論文 集（ISSN 0917-5555）

*：1994年 6 月より，「プリント回路学会」は「回路実装学 会」と名称が変更された。

1) 中村英博：“伝送線路電気特性評価方法の险路についての 考察”, B-2委報 ; 研報B, p.9（1993）

2）首藤克彦：“落雷による家電機器の障害”, B-2委報; 研報 B, pp.10-11 (1993)

3）徳重寛吾, 他：“TEMセルを用いたパーソナルコンピュー タのイミュニテイ測定と評価”, B-2委報;研報B, pp.12-13 (1993)

4）佐藤政生：“BEAR：次世代ビルデイングブロック・レイア ウト・システム”, B-2委報 ; 研報B, p.14（1993）

5）渋谷昇：“プリント配線板におけるノイズ対策技術”, 研論, Vol.1, No.1,pp.1-6 (1991)

6）首藤克彦：“雷現象とそれによる電子機器の障害”, 研論, Vol.1, No.1, pp.7-12 (1991)

7）徳重寛吾,他：“TEMセルを用いたパーソナルコンピュータ のイミュニテイ測定と評価”, 研論, Vol.1, No.1, pp.13-18 (1991)

8）諸橋欣一：“プリント配線板ノイズ対策技術の動向”, 研論, Vol.1, No.1, pp.19-24 (1991)

9）森崎慎也,他：“プリント回路のクロストークー中央遮蔽導 体の接地と遮蔽効果一”, 研論, Vol.1, No.1, pp.25-30 (1991)

10）角憲明：“TCPにおけるCMOS LSIの同時スイッチングノ イズの評価”, B-3委報 ; 研報B, p.15（1993）

11）周英明,他：“理科大電気工学科周 - 越地研究室研究活動紹 介”, B-3委報 ; 研報B, pp.16-17（1993）

12）高橋丈博：“電磁放射ノイズシミュレータの評価につい て”, B-3委報 ; 研報B, p.18（1993）

13）周英明：“信号の伝搬速度について”, 研論, Vol.1, No.2, pp.1-6 (1991)

14）西方敦博：“多層基板の近傍電磁界解析のためのGreen関 数の定式化”, 研論, Vol.1, No.2,pp.7-12（1991）

15）金子俊之,他：“放射ノイズ予測のための電流ループの検討”, 研論, Vol.1, No.2, pp.13-18 (1991)

16）出口博一, 他：“スイッチング電源の E M I 対策”,研論, Vol.1, No.2, pp.19-24 (1991)

17）大西輝夫, 他：“F D-T D 法を用いたマイクロストリップ アンテナの解析”,研論,Vol.1, No.2, pp.25-32 (1991)

18）大滝徹：“テスト基板の E Mスキャンdifferentialノイズの 測定”, B-4委報（文献44）, 45）参照)

19）林昌世：“電子機器筐体表面の電流分布解析”， B-4委報 （文献26）参照)

20）勅使河原治：“3次元実装の一例と信頼性”, B-4委報；研 報B, p.20（1993）

21）松井則夫：“配線・接続部を考慮したノイズシミュレータ”, B-5委報（文献27）参照)

22）須藤俊夫：“マルチチップ・モジュールと電気設計”，B-5 委報；研報B, p.19（1993）

23）山本裕三：“導電性複合材料一金属及びポリマーの表面特 性について”, 研論, Vol.1, No.3, pp.1-8（1992）

24）松永茂樹：“銅ペーストによる E M I 対策配線板の放射， イズ低減特性”,研論, Vol.1, No.3, pp.9-16（1992）

25）中村英博：“マルチワイヤの伝搬特性”, 研論, Vol.1, No.3, pp.17-26 (1992)

26）林昌世：“電子機器笚体表面の電流分布解析”, 研論, Vol.1, No.3, pp.27-34 (1992)

27) N. Matsui et al. : “Interconnection Noise Simulation”, 研論, Vol.1, No.3, pp.35-41 (1992)

28）河上功：“プリント基板設計へのシミュレータの利用”, B-6委報（口頭発表）

29）柳本太加志：“伝送線路シミュレータを使用したレイアウ 卜設計”，B-6委報；研報B, p.21（1993）

30）越地耕二：“共平面形線路の直角ベンド”, B-7委報 ; 研報 B, p.23 (1993)

31）村田雄司：“入門教育講座「静電気の発生と障害」”, 研論, Vol.2, No.1, pp.1-6 (1992)

32）栗島亭,他：“ラバーバンド表現に基づいたグリッドレス。 ルータ”, 研論, Vol.2, No.1, pp.7-12（1992）

33）田邊浩介, 他：“衛星通信用多層プリントアンテナ”, 研 論, Vol.2, No.1, pp.13-20（1992）

34）和田修己, 他：“高速ディジタルプリント回路基板の近傍 電磁雑音の要素分解”, 研論, Vol.2, No.1, pp.21-28（1992）

35）福川弘：“多層銅張積層板の電気特性”, B-8委報 ; 研報 $\mathrm{B}$, pp.24-25（1993）

36）中村英博：“三次元伝送線路シミュレータの適用検討”, B-8回報 ; 研報B, pp.26-27（1993）

37）首藤克彦：“雷害による破壊例”, B-8委報（口頭発表） 
38）佐藤政生：“柔軟性の高いレイアウト戦略ーラバーバンド 表現に基づいたグリッドレスレイアウトシステムー”, B-9 委員報 ; 研報B, p.28（1993）

39）林昌世：“金属筐体電磁波漏洩数値実験”, B-9委報； 研 報B, pp.29-30（1993）

40）青木正光：“入門教育講座「プリント配線板用銅張積層 板」一材料の種類とその応用例について一”, 研論, Vol.2, No.2, pp.1-12 (1992)

41）高橋丈博,他：“事例を用いたノイズ理解支援システムの開 発”, 研論, Vol.2, No.2, p.13-16（1992）

42）澤佐博行,他：“共平面形線路の円形曲がり部の透過特性”, 研論, Vol.2, No.2, pp.17-24 (1992)

43）勝山芳郎,他：“EMIシミュレーションで何ができるかー EMI対策からEMI設計への転換一”, 研論, Vol.2, No.2, pp.25-31 (1992)

44）大滝徹：“プリント基板設計に関する現状の課題”， B-10 委報；研報B, p.31（1993）

45）大滝徹：“放射ノイズの基礎検討”, B-10委報 ; 研報 B, p.32 (1993)

46）河上功：“電気特性考慮のポイント”, B-10委報（口頭発 表)

47）越地耕二：“電子情報通信学会環境電磁工学研究専門委員 会主催, 電子機器のEMC設計・対策一理論と実際一ワーク ショップ (湯沢)”, B-10委報（口頭発表）

48）周英明：“プリント回路学会技術研究委員会主催, EMI/C ワークショップ (湯河原)”, B-10委報（口頭発表）

49）堀田幸雄：“入門教育講座「EMCの測定と対策」”, 研論, Vol.2, No.3, pp.1-8 (1993)

50）松永茂樹：“ロジックICの特性を考虑したノイズ対策”, 研論, Vol.2, No.3,pp.9-14（1993）

51）池田三喜夫,他：“高速デジタル回路設計の検証”, 研論, Vol.2, No.3, pp.15-24 (1993)

52）前田真一：“レイアウトツールとシミュレータの統合化”, 研論, Vol.2, No.3, pp.25-31 (1993)

53）島山鶴雄：“電磁調理器よりの漏洩電磁界”, 研論, Vol.3, No.1, pp.1-4 (1993)

54）渋谷茂一，他：“EMCサイトの自由空間化（2）ーイミュ ニティー勧告案の問題点と指定領域の自由空間化一”,研論 Vol.3, No.1, pp.5-10（1993）

55）横島一郎,他：“モノポールアンテナの複素アンテナファク タの測定”,研論，Vol.3, No.1,pp.11-16（1993）

56）横島一郎,他：“三アンテナ法によるグランドプレーンのダ イポールアンテナのアンテナファクタ測定”, 研論, Vol.3, No.1, pp.17-22 (1993)

57）篠塚隆,他：“曲がりのあるプリントパターンからの放射”, 研論，Vol.3, No.1, pp.23-28（1993）

58）澤佐博行,他：“共平面線路の角形曲がり部の放射特性”, 研論, Vol.3, No.1, pp.29-34（1993）
59）樽井勇之,他：“放射を考慮した部品配置支援ツール”,研論, Vol.3, No.1, pp.35-39 (1993)

60）勅使河原治：“シールド効果を強化した高密度実装”，C-2 委報

61）高橋丈博: “抵抗を接続したパスコンの効果”，C-2委報，研 報C, pp.9-10（1995）

62）澤佐博行: “共平面形線路の曲がり部の透過特性一角形と円 形曲がり一”, C-2委報, 研報C, p.11（1995）

63）和田修己：“電子情報通信学会環境電磁工学研究専門委員 会ワークショップ（湯沢）報告”, C-3委報

64）和田修己：“ノイズ対策のための配線”，C-3委報（口頭発 表)

65）諸橋欣一：“プリント配線板の伝送特性と改善方法”, C-3 委報, 研報C, pp.15-16（1995）

66）瀬戸信二：“パソコンからの電磁的情報漏洩対策の現状”, 研論, Vol.3, No.2, pp.1-8 (1993)

67）松永茂樹: “ICの選択とディジタル配線板の電源系差動モー ドノイズ低減法”,研論,Vol.3, No.2, pp.9-14（1993）

68）古谷親生,他：“高速ディジタル回路パターンにおけるクロ ストーク”, 研論, Vol.3, No.2, pp.15-20（1993）

69）山田茂貴,他：“衛星通信用多層プリントアンテナー特性改 善と薄形化一”,研論, Vol.3, No.2, pp.21-29（1993）

70）森元昌平：“ディップコートタイプポリマー型銅ペースト”, C-4委報，研報C, pp.17-18（1995）

71）松永茂樹：“ノイズ低減のための能動素子の選定”，C-4委 報，研報C, pp.19-20（1995）

72）松井則夫：“伝送線路と放射雑音のシミュレータ”，C-4委 報（口頭発表）

73）伊藤健一：“パスコンではなく，スナバーだ!一高損失化, 高 $\varepsilon$ 化こそ本命一”,研論,Vol.3, No.3,pp.1-24（1994）

74）森元昌平：“銅ペーストによるEMC対策の動向”, 研論, Vol.3, No.3, pp.25-34 (1994)

75）五味久喜：“機器のEMC”, 研論, Vol.3, No.3,pp.35-44 (1994)

76）高橋丈博,他：“等価回路網法による放射ノイズ計算”，研 論, Vol.3, No.3, pp.45-50 (1994)

77）堀田幸雄：“タイムドメイン・イミュニテイ測定システム”, C-5委報（文献98）参照）

78）林昌世：“電磁波源の数值解析とEMC問題への応用一金属 筐体モデルー”, C-5委報，研報C, pp.21-22（1995）

79）角憲明：“LSIの出力同時変化の許容值（シミュレーショ ン)”, C-6委報 (口頭発表)

80）中村英博: “転写法による自動検査用PCB”，C-6委報（口頭 発表)

81）久保田達也,他：“マイクロストリップ線路のグランド導体 のスロットと信号伝送特性”,研論, Vol.4, No.1,pp.1-8 (1994)

82）久保博,他：“多層プリント回路基板のグランド面のスリッ 
トにより増加する放射電磁波の低減法”, 研論, Vol.4, No.1, pp.9-16 (1994)

83）松永茂樹：“放射ノイズレベルを低減するディジタルプリ ント配線板の設計”,研論, Vol.4, No.1,pp.17-24（1994）

84）高橋丈博,他：“抵抗つきパスコンによるノイズ低減効果”, 研論, Vol.4, No.1, pp.25-32（1994）

85）黒内利明, 他：“微小領域におけるノイズセンシング技術 の研究”,研論, Vol.4, No.1,pp.33-38（1994）

86）沼澤佳宏, 他：“抵抗皮膜を用いた格子状電波吸収壁の解 析”,研論, Vol.4, No.1, pp.39-44 (1994)

87）長尾泰司,他：“平板シールドによる近傍電磁波源の変換作 用”,研論，Vol.4, No.1, pp.45-50 (1994)

88）半田晋之,他: “デジタル回路上の誘起雑音信号と誤動作機 の実験的検討”，研論,Vol.4,No.1, pp.51-58（1994）

89）上村一司,他：“自動車の静電気制電性能の実験法の開発”, 研論, Vol.4, No.1, pp.59-64 (1994)

90）半杭英二,他：“磁界印加形プリント基板用イミュニテイ評 価装置”,研論, Vol.4, No.1, pp.65-70（1994）

91）越地耕二：“共平面形線路の曲がり部の透過特性の改善”, C-7委報, 研報C, p.23（1995）

92）山口正憲：“Transient Analysis of Dispersive Signal Line Terminated with CMOS Devices”, C-7委報, 研報C, pp.25-26 (1995)

93）中村英博：“PCB自動検查システム”, C-7委報（口頭発 表)

94）大滝徹：“プリント基板から反射するノイズ”, C -8委報, 研報C, p.27（1995）

95）太田義昭,他：“共平面形線路のクロストーク”, 研論, Vol.4, No.2, pp.1-12 (1994)

96）高橋丈博,他：“ICパッケージのリードパラメータの検討”, 研論, Vol.4, No.2,pp.13-18 (1994)

97）勅使河原治,他：“携帯電話用3次元実装技術と電気回路特 性”, 研論, Vol.4, No.2, pp.19-24（1994）

98）堀田幸雄：“タイムドメイン・イミュニテイ測定システム”, 研論, Vol.4, No.2, pp.25-28 (1994)

99）上芳夫：“Intern. Symp. EMC’ 94/Roma”, C-9委報（口頭 発表)

100）柳本太加志：“多層基板の層構造による放射電界強度の 違い”, C-10委報, 研報C, p.28（1995）

101）中村直準,他：“平行ストリップ線路給電による多層プリ ントアンテナ”, 研論, Vol.4, No.3, pp.1-8（1995）

102）戸花照雄,他：“有限プリント基板の近傍磁界測定”, 研論, Vol.4, No.3, pp.9-14 (1995)

103）藤尾昇平,他：“シミュレーション技術によるEMC設計の
実践”, 研論, Vol.4, No.3,pp.15-20（1995）

104）猪腰勇：“インターコネクト・パラメータ・アナライザ を用いたパッケージの電気的特性評価とモデリング”, 研 論, Vol.4, No.3, pp.21-26 (1995)

\section{1 解析理論関連}

A1) C.R.Paul : "Introduction to Electromagnetic Compatibility", John Wiley \& Sons Inc. (1992)

A2）山下栄吉監修：“電磁波問題の基礎解析法”, 電子情報通 信学会, 1987年

A3）山下栄吉監修： “電磁波問題解析の実際”, 電子情報通信 学会, 1993年

\section{口. 2 測定理論関連}

B1）川上功: “プリント配線板の伝送特性のシミュレーション および実測”，サーキットテクノロジ, Vol.7,No.3, pp.175182 (1992)

B2）五十嵐力, 柳本太加志：“測定技術－E M I の簡易測定と サイト測定” , サーキットテクノロジ,Vol.9, No.4, pp.243247 (1994)

B3）高谷和宏, 他: “ディジタル回路が構成するループの共振 による放射電磁雑音スペクトルの表現”，信学技報， EMCJ94-55 (1994-11)

B4）和田修己, 他：“CMOS論理ICの電気的特性の違いによる プリント回路からの放射電磁雑音量の変動”, 信学技報, EMCJ93-39 (1993-09)

B5）和田修己，他：“ディジタルICのパッケージ種類と放射電 磁雑音”, サーキットテクノロジ, Vol.9, No.3, pp.175-182 (1994)

B6）松本史生, 他：“ディジタル基板に誘起される電磁雑音と 回路の誤動作”，信学技報, EMCJ92-88（1993-03）

\section{-3.1 部品による対策関連}

C1) Y.Hotta, et al. : "Effect of Line Impedance on Radiated Emission”, IEEE EMC Symposium 1992

C2) Y.Hotta et al. : "EMI from personal computers", IEEE EMC Symposium Record 1985

C3) Y.Hotta et al. : "The Magnetic Characteristic of the suppressing noise generated by a phase controlled thyristor", IEEE EMC Symposium Record 1975

C4）堀田幸雄：“パーソナルコンピュータのEMI対策例”, 信 学会EMCJ 1983

C5) CISPR Publication 16

C6) CISPR Publication 17

C7) Y.Hotta et al. : "EMI from personal computers", IEEE EMC Symposium Record 1985 


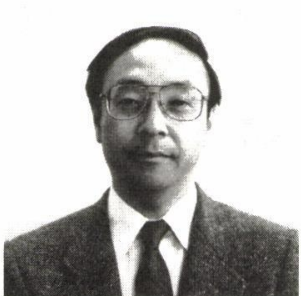

越地 耕二(こしじこうじ)

昭和 22 年生まれ。昭和 47 年東京理科大学 大学院工学研究科電気工学専攻修士課程 修了。現在, 同大学助教授。工学博士。 電波システム，医用電子工学，特に超高 周波帯におけるプリント回路の電磁特性 解析に関する研究等に従事。

林 昌世（はやししょうせ）

昭和 24 年生まれ。昭和 57 年東京大学理学 系地球物理学博士課程中退。現在, 株式 会社NEC情報システムズにおいて， EMC関連数值解析・シミュレーション の開発に従事。

澤佐 博行（さわさ ひろゆき）

昭和 33 年生まれ。平成7年東京理科大学 大学院理工学研究科電気工学専攻博士後 期課程修了。現在, 防衛庁技術研究本部 に抢いて，通信機の研究開発に従事。

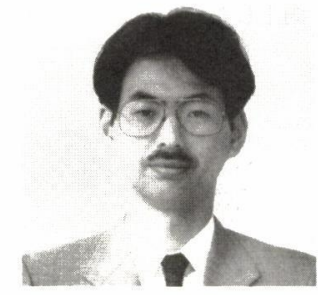

和田 修己（わだ 扮さみ）

昭和32年生まれ。昭和62年京都大学大学 院工学研究科電子工学専攻博士課程修 了。現在, 岡山大学工学部電気電子工学 科助教授。ディジタルプリント回路板の 放射性EMIの予測法に関する研究に従 事。

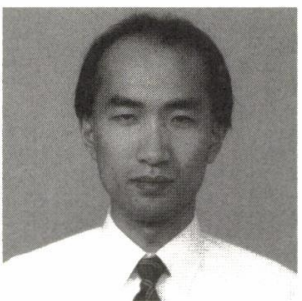

高橋 丈博（たかはしたけひろ）

昭和38年生まれ。昭和62年東京農工大学 大学院工学研究科電子工学専攻修了。昭 和63年拓殖大学工学部情報工学科助手。 工博。プリント配線板における伝導性拉 よび放射性雑音の研究に従事。

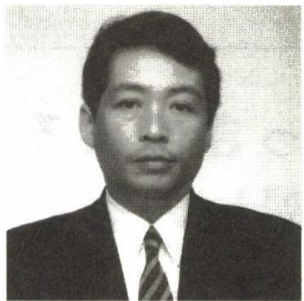

堀田 幸雄（ほったゆきお）

昭和 24 年生まれ。昭和 47 年, 近畿大学理 工学部電子工学科卒業。現在, 株式会社 トーキンに扔いて, 電磁妨害波やイミュ ニティ問題に対する計測，対策技術の開 発に従事。

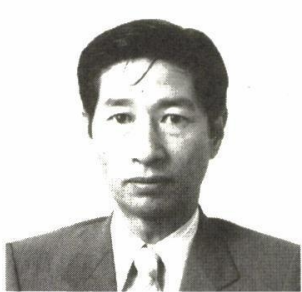

松永 茂樹（まつなが しげき）

昭和10年生まれ。昭和 29 年徳山曹達株式 会社（現・株式会社卜クヤマ）に入社。 昭和 38 年国立宇部工業短期大学電気科卒 業。電気・計装，セメント製造，プラン 卜建設に携わり, 昭和 63 年よりプリント 配線板の設計業務に従事。

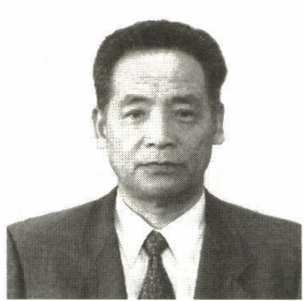

諸橋 欣一(もろはしきんいち)

昭和 8 年生まれ。昭和 34 年, 工学院大学 電気工学科卒業。現在, 株式会社シイエ ムケイ回路設計センター回路設計部にお いて, PWBの伝送特性の研究と,イズ 対策，およびCAD設計，VE設計などに 従事。

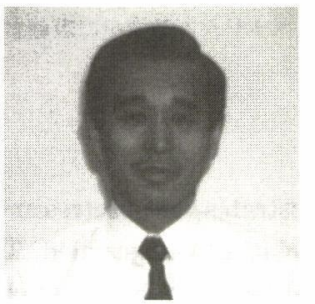

勅使河原 治（てしがわら おさむ）

昭和 23 年生まれ。昭和 45 年, 東京理科大 学工学部電気工学科卒業。現在, 日本無 線株式会社研究所において, 携帯電話用 のデバイス拉よび実装技術開発に従事。 